\title{
PBL における「ほめ」効果について
}

On Praise Effects in PBL

$\begin{array}{cll}\text { 五百井 俊 宏*1 } & \text { 森 田 洋 介 }{ }^{* 1} & \text { 山 崎 晃*1 } \\ \text { Toshihiro IOI } & \text { Yosuke MORITA } & \text { Akira YAMAZAKI }\end{array}$

\begin{abstract}
Project-based learning (PBL) has been introduced at many educational institutions and had a considerable effect on human resource development. However, researchers have pointed out that PBL performance can be diminished by a lack of basic management skills among participants or a general sense among them that they are simply being told what to do. We anticipate that PBL performance can be improved by identifying meta-competencies capable of being developed by PBL and introducing praise to the PBL process. In this study, we investigate the effectiveness of praise within PBL by means of structural equation modeling. Our results suggest that the satisfaction of PBL participants can be increased by identifying developable meta-competencies and applying a praise model under the MEH model.
\end{abstract}

Keywords : Project-based Learning, Structural Equation Modeling, Praise Model, MEH Model キーワード：プロジェクトベース教育, 共分分散構造解析, ほめモデル, MEHモデル

\section{1. 緒論}

人はほめられると自己効力感が高くなり，その後の 学習効果や行動従事に大きな影響を与えることが報告 されている1).また「ほほ」が人に自信を持たせ積極 的な行動につながることから, イノベーションを誘引 する重要な要素であることも指摘されている ${ }^{2)}$. 従来, プロジェクトベース学習 (PBL) を導入した人材育成 法に関する多くの有益な研究が報告されている．森田 等は,「ほめ」を導入したPBLを実行し,メンバのコ ンピテンシーと「ほめ」との関連性について検討した. その結果,「ほめ」がPBLメンバの行動変容を促し, PBLに対する満足度を向上させることを明らかにして

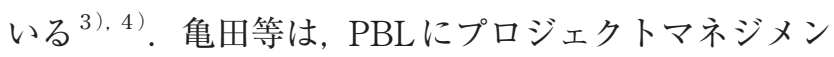
トオフィス $(\mathrm{PMO})$ を導入すれば, PBLの問題解決 を支援することが可能となることを報告している ${ }^{5)}$. しかしながら, PBLパフォーマンスを向上させるため に, PBL運用中に「ほめ」を考慮し, その効果を検証 した研究はあまり報告されていない。新規ビジネス提 案を目的としたPBLで,メンバの育成可能なコンピテ ンシーを特定し, PBL 運用中に「ほめ」を導入すれば, PBLパフォーマンスを向上させることが期待できる.

本研究の目的は, PBLを活性化するためにほめモデ ルを提案し,「ほめ」とマネジメント因子との関連性を 共分散構造分析（以下, SEM）により評価することで ある. 大学における PBL型授業であるプロジェクトマ

2016 年 1 月 12 日受付

$※ 1$ 千葉工業大学
ネジメント（PM）演習を事例とし, メンバの社会人基 礎力と「ほめ」との関連性についてSEMを用いて解析 した，その結果,「ほめ」の有無による2つのSEMモデ ルを比較することにより, PBLメンバの満足度を向上 させるためのマネジメント因子と「ほめ」との関連性 を明らかにすることができた，そして，「ほめ」とコン ピテンシーで構成される $\mathrm{PBL}$ パフォーマンスモデルを PBLで活用すれば，効果的な人材育成が期待できる.

\section{2. ほめに関する先行研究の概要}

「ほめ」に関する研究は, 主として心理学の動機づけ 理論を基に実施され, 多くの研究成果が報告されてい る $^{6)}$. それによると,「ほめ」が学習効果や行動従事一 与える影響を強めるための強化子として位置づけられ ている. ほめ手視点の研究として, Brophyは, 教師の 工夫によるほめ方のガイドラインを提案している ${ }^{7)}$. 「ほめ」の受け手視点の研究として, Henderlongは, 「ほめ」の効果がほめ手から受け手に対する一方向の 働きかけではなく複雑な社会的コミュニケーションで あることを指摘している ${ }^{8)}$. 高崎等は, ほめ手が受け 手にポジティブに受け止められなかった要因として, ほめる側, ほめられる側, そして双方の原因に分類し ている ${ }^{9)}$. 青木は, 感謝の表明や励ましも「ほめ」と 認識される場合があることを明らかにした ${ }^{10)}$. 笹川等 は, ほめられた人は, その後の自己効力感が高いこと を明らかにした ${ }^{1)}$. 動機づけや達成感視点の研究とし て, Kaminsは, ほめる際の焦点の当て方により, そ の後の失敗経験による無力感反応が異なることを明ら 


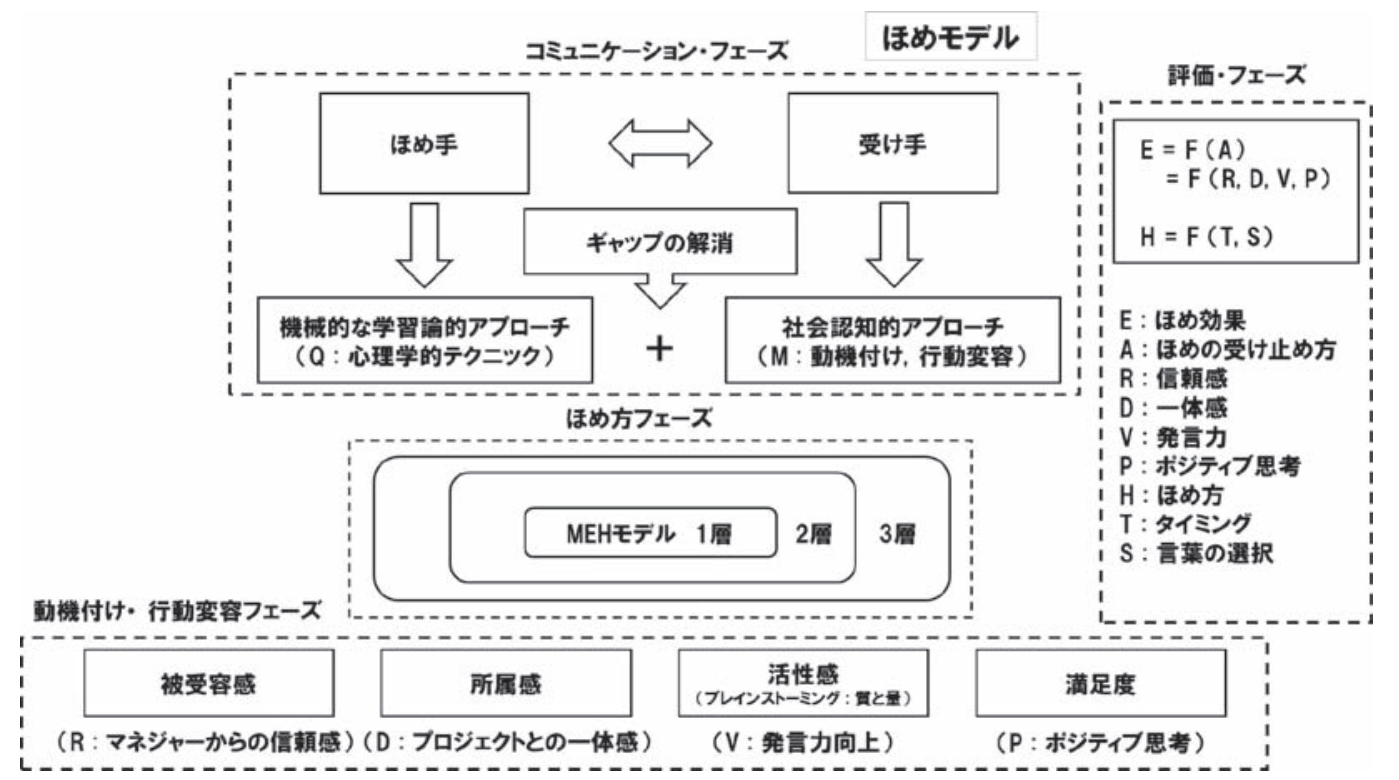

図 1 ほめモデル

かにした ${ }^{11)}$. Kast は,「ほめ」の条件として，情報的 フィードバッグ, 統制的フィードバッグ, 混在フィー ドバッグを提案している ${ }^{12)}$. 以上に述べたように,「ほ め」に関する多くの研究が報告されているが, PBLの 活性化のために「ほめ」を応用した研究は，ほとんど 見られない.

\section{3.ほめモデル}

図 1 にほめモデルを示す ${ }^{3), 4)}$. このモデルは、コ ミュニケーションフェーズ, ほめ方フェーズ, 動機づ け・行動変容フェーズ，そして評価フェーズに分類さ れる。コミュニケーションフェーズでは，ほめ手と受 け手で「ほめ」に関するやりとりが行われる。ほめ手 の発信が心理学をべースにした機械的・学習論的なア プローチのみの場合, 受け手の認知を考慮したものと はならず，ほめ手と受け手の間で，ほめ効果に関する ギャップが生じる。一方, ほめ手が受け手の社会認知 的アプローチを考慮した場合には，ほめ手と受け手の ギャップが削減され，「ほめ」に対する大きな効果が期 待できる。ほめ方フェーズには，MEH（森本・榎田・ 原田）モデルを導入する ${ }^{13}$. MEHモデルの 1 層は人格 や遺伝子等の生まれつきの状態を指す. 2 層は知恵, 経 験，スキル等の蓄積されたものを指す。そして 3 層は 行動, 発言, 成果等の外に現れるものを指す。受け手 のほめ効果を表す動機づけ・変容行動フェーズは, 被 受容感, 所属感, 活性感, そして満足度に分類される. メンバはPBLでほめられることにより，マネジャーか ら信頼されている感じ（被受容感）を認識し，プロジ エクトとの所属感 (一体感) や活性感（発言での質と 量の向上）を向上できる. そして自己効力感が改善さ れればPBLメンバの満足度向上が期待できる，評価フ ェーズでは，ほめの効果を把握するため，式 (1), (2) に示す評価式を提案する ${ }^{3)}$.

$$
\begin{aligned}
& \mathrm{E}=\mathrm{F} \quad(\mathrm{A})=\mathrm{F} \quad(\mathrm{R}, \mathrm{D}, \mathrm{V}, \mathrm{P}) \\
& \mathrm{H}=\mathrm{F}(\mathrm{T}, \mathrm{S})
\end{aligned}
$$

ここで, 式 (1)，(2) で用いた記号は以下の通りであ る.

$\mathrm{E}:$ ほめの効果 $(\mathrm{R}, \mathrm{D}, \mathrm{V}, \mathrm{P}$ の関数)

$\mathrm{H}$ : ほめ方 ( $\mathrm{T}, \mathrm{S}$ の関数)

$\mathrm{A}:$ :めの受け止め方

$\mathrm{R}$ ：マネジャーからの信頼感

$\mathrm{D} ：$ プロジェクトにおける所属感（一体感）

$\mathrm{V}$ : 活性感 (発言力等)

$\mathrm{P}$ : 満足感 (ポジティブ感)

$\mathrm{T} ：$ タイミング

$\mathrm{S}$ : 言葉の選択

ほめ方 $\mathrm{H}$ は, ほめるタイミング $\mathrm{T}$ と言葉の選択 $\mathrm{S}$ の 関数であり，心理学を基に具体的な方法が提案されて いる ${ }^{9)}$. ほめの効果 $\mathrm{E} は$, ほめの受止め方 $\mathrm{A}$ の関数で あり，受け手からのレスポンスにより評価される。A はマネジャーからの信頼感 (被受容感), プロジェクト に扔ける所属感 (一体感), 活性感 (発言力等), そし て, 満足感（ポジティブ感）に分類される.

\section{PBLパフォーマンスモデル}

PBLのパフォーマンスを向上させるためには, メン バのコンピテンシーやスキルの育成, そしてモチベー ションの向上を図ることが重要である。本研究では, 佐藤（所属は発行当時）らにより提案された組織パフ オーマンス向上のためのモデルを参考にPBLパフォー マンスモデルについて検討した $(\text { 図 } 2 \text { 参照 })^{14)}$ 。この モデルは, メンバの課題遂行力とプロジェクトモチベ ーションの積で構成される. 佐藤らは, 課題遂行力を 複数のコンピテンシーに影響を与えるメタ・コンピテ ンシーとスキルの積で示し個力と定義している，そし てメタ・コンピテンシーの事例として,「創意工夫取 


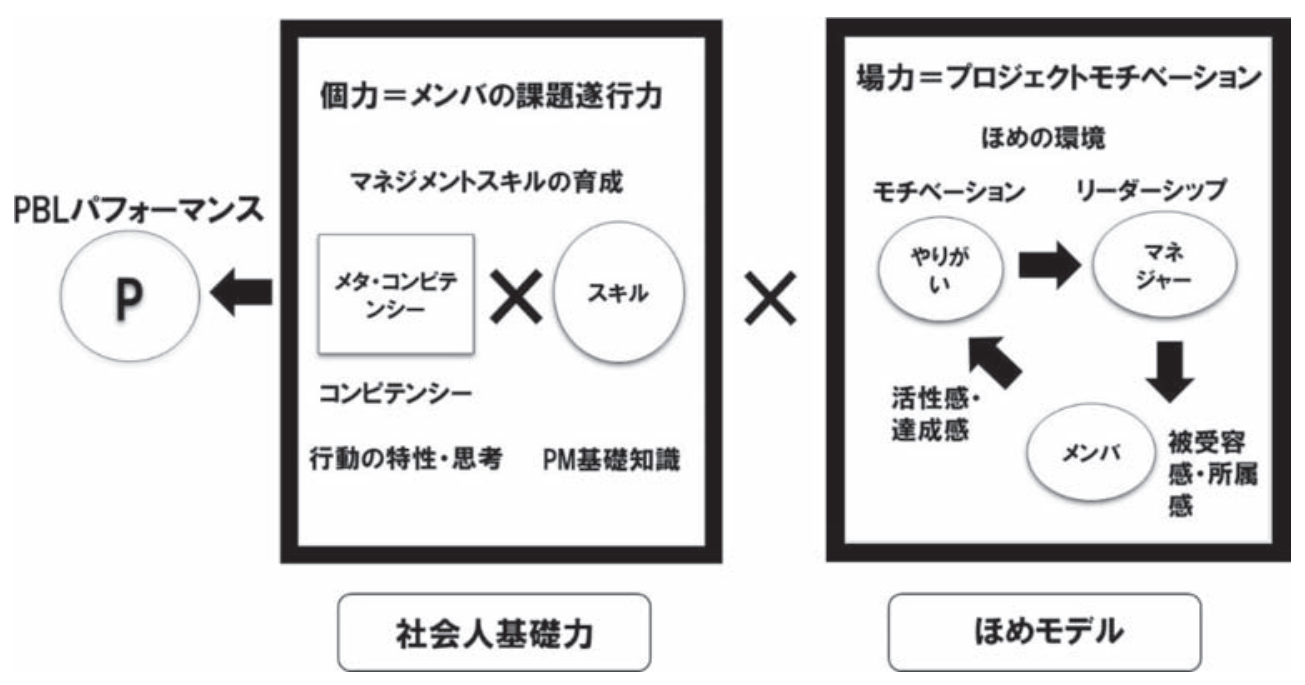

図 2 PBL-パフォーマンスモデル

り組み」,「責任感」,「協調性」の3つをあげている. 一方, 組織モチベーションは, リーダーシップ, メン バ, やりがいの連鎖で示され，場力と定義している ${ }^{14)}$. 本研究では, ビジネス創成を目的としたPBL型授業の パフォーマンス $(\mathrm{P})$ を向上させるために, コンピテン シーとしてシンキング, アクション, チームワークで 構成される社会人基礎力を設定した。 PM基礎知識と 社会人基礎力におけるメタ・コンピテンシーを育成す れば個力を向上させることが期待できる。一方，リー ダーが「ほめ」を考慮したコミュニケーションを取れ ば,メンバは被受容感, 所属感，やりがいを感じ，そ の結果，プロジェクトモチベーションの向上により場 力を向上させることができる，そして個力と場力の積 により PBLの活性化を評価することが可能となる，以 上に述べたように，ビジネス創成を目的としたPBLで 社会人基礎力におけるメタ・コンピテンシーを特定し, PBL 運用中に適正な「ほめ」を導入すればPBLの活性 化により効果的な人材育成が期待できる.

\section{PBLにおけるほめ効果の検証}

\section{1 PBLアンケート調査の概要}

本研究では，大学で実施しているPBL型授業を対象 に基礎的なマネジメントスキルとPBL実施中にメンバ が感じる意識についてアンケート調査を行った。調査 対象は, 千葉工業大学社会システム科学部プロジェク トマネジメント学科の「プロジェクトマネジメント演 習 (ビジネス創成提案)」を受講した 3 年生計 9 人 (男 性 8 人, 女性 1 人）であり， 3 グループ（1 グループ, 3 人）のデータを採用した. アンケート調查項目は, 社会人基礎力（シンキング，アクション，チームワー ク）に関する 12 項目，プロジェクトマネジメントスキ ル 2 項目，心理学的要素に含まれる「ほめ」に関する 4 項目, そして総合満足度の合計19項目を設定し, 学 生による5段階自己評価を採用した。各週の作業終了 時に研究室のティーチングアシスタント（TA）が被

\begin{tabular}{|c|c|c|}
\hline \multicolumn{2}{|r|}{ アンケート項目の分類 } & アンケート項目 \\
\hline \multicolumn{2}{|c|}{ 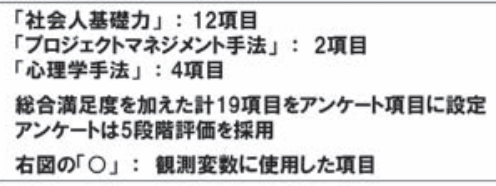 } & \multirow{8}{*}{ 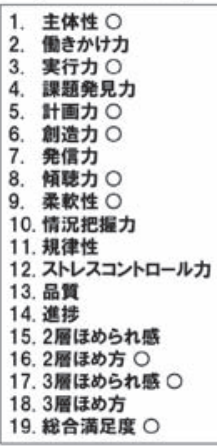 } \\
\hline No. & スキルと手法の分䫫 & \\
\hline $1-3$ & 社会人甚蕞力 (アクション) & \\
\hline $4-6$ & 社会人勘起力 (シンキング) & \\
\hline $7-12$ & 社会人基䖽力 (チームワーク) & \\
\hline 13 & フロジェクトマネジメント手法（品賽マネジメン） & \\
\hline 14 & フロジェクトマネジメン手法 (タイムマネジメント) & \\
\hline $\begin{array}{c}15- \\
18\end{array}$ & 心理学手法（MEHモデル） & \\
\hline
\end{tabular}

図 3 アンケート調査項目の分類

験者である学部 3 年生のアンケート調査結果を収集し た。図 3 にアンケート調查項目の分類を示す。調査期 間は2015年 4 月10日から2015年 7 月17日までの 4 か 月間（合計14回分のPM演習）である。アンケート調 查は, ビジネス創成を目的としたPBL型授業を対象に 実施された。調查対象学生数は少ないが，PM演習の 前に実施される $\mathrm{PM}$ 実験でのアンケート調査結果の回 答でもほほ同様の傾向を示すことから, 調查解析デー タとして問題がないと判断した。 これは, ビジネス創 成の内容が，主に事例分析とビジネス提案で構成され ているためと考えられる。

\subsection{SEMモデルによるほめ効果の評価}

本研究ではPBLでのアンケート調查結果で得られ たマネジメントスキルの中でビジネス創成のための基 礎スキルである社会人基礎力と「ほめ」との関連性に 着目した。 そして, 解析方法として, 社会人基礎力と 「ほめ」による行動変容を分析するため因子分析と回帰 分析を同時に実行することが可能な多変量解析である SEMを用いた。「ほめ」の有無による2つのSEMモデ ルを作成すれば, 社会人基礎力におけるメタ・コンピ テンシーの特定と「ほめ」による行動変容の特徵を分 析することができる. SEMによる分析では, 斜交回転 による確認的因子分析を採用した，図 4 に「ほめ」の 

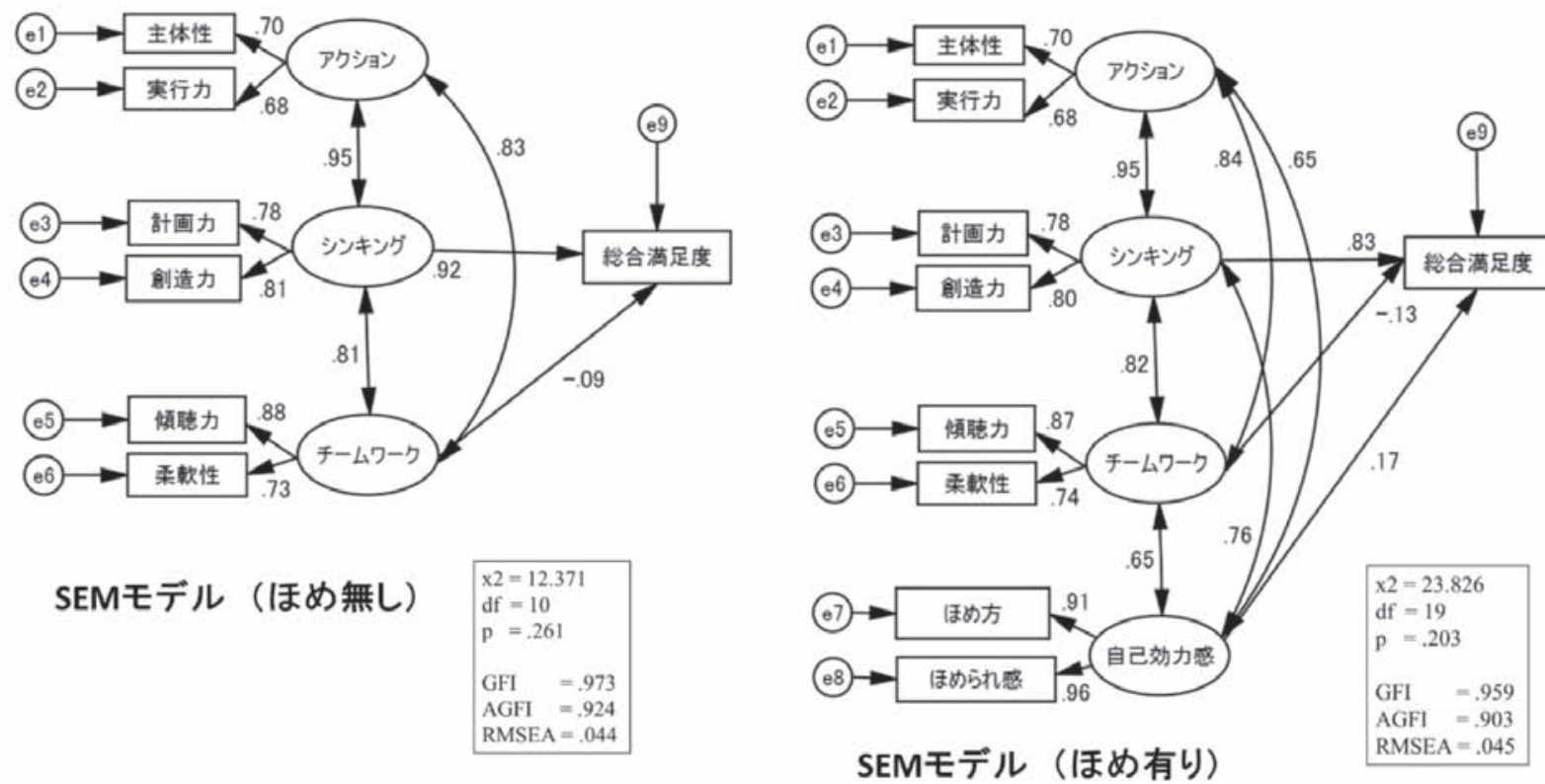

図 4 共分散構造分析 (SEM) モデル

有無による2つSEMのモデルを示す。「ほめ」を考慮 しない場合のSEMモデルの潜在変数は, 社会人基礎力 のアクション，シンキング，チームワークであり，そ れぞれに対応する観測変数として, 主体性, 実行力, 計画力, 創造力, 傾聴力, 柔軟性の 6 項目を設定した. 一方，ほめを考慮した場合のSEMの潜在変数は, 社会 人基礎力の 3 項目に自己効力感を加えた 4 項目とし, 自己効力感の観測変数として, ほめ方とほめられ感の 2 項目を追加した。 そして，メ夕・コンピテンシーと メンバの行動変容に関して, 以下の仮説を設定した.

（1）社会人基礎力における観測変数と潜在変数のパス 係数を基にメタ・コンピテンシーの特定が可能であ る.

(2)「ほめ」により自己効力感が向上する.

以上の仮説を基に 2 つのSEMモデル（図 4 参照）を 作成し, モデルの妥当性を評価指数により確認した。 図 4 に示す誤差変数(e) は潜在変数の一種であるが, 観 測変数から共通性を除いた独自の成分と測定誤差の両 方を含んでいる.

「ほめ」の有無による2つのSEMモデルを用いれ ば，因子間の関連性をパス係数で数值化することによ り, 社会人基礎力におけるメタ・コンピテンシーの特 定,「ほめ」とその他の因子との因果関係, そしてメン バの総合満足度を定量的に評価することができる。

以下にSEMモデルによる分析結果を示す.

「ほめ」によるメンバの満足度に着目すると,「ほ め」を考慮しない場合のSEMモデルでは, シンキング を中心に創造力と総合満足度へのパス係数が，それぞ れ0.81，0.92と高くなり，これらの項目間の相関が強い ことが分かった，そこで，「ほめ」を考慮したSEMモ デルでシンキングを中心に「ほめ」とその他の因子と の因果関係について検討した。 その結果, シンキング
を中心に創造力と総合満足度へのパス係数は, それぞ れ0.80,0.83となり, ほめが無い場合のパス係数と比較 するとやや低い值となったが, ほほ同様の傾向を示し た，一方，ほめ方，ほめられ感と自己効力感とのパス 係数は，それぞれ0.91，0.96と非常に高い相関を示した が, 自己効力感と総合満足度とのパス係数は 0.17 と低 いことが分かった. このことは, 自己効力感の改善が 必ずしもメンバの満足度を向上させないが, 自己効力 感とシンキングのパス係数が0.76となり，「ほめ」との 関連性が高いことが分かった。 アクションとチームワ ークについては,「ほめ」の有無に関わらず，それぞれ 主体性と実行力，および傾聴力と柔軟性との相関が高 いことが分かった。ビジネス創成を目的としたPBLで は, 総合満足度と最も関連性の高い因子は社会人基礎 力に抒けるシンキングであり, 特に計画力と創造力を メタ・コンピテンシーとして特定できることが分かっ た.このことは, 学生が優れたビジネス提案をするた めにPBLでユニークなアイデイアを出し, 計画に沿っ て成果物を獲得する努力を行っていることを示す。さ らに,「ほめ」がメンバの自己効力感を向上させるため, PBL 運用中にリーダーやメンバが適正な「ほめ」を導 入すれば, メンバの行動変容（シンキング）を誘発す ることが期待できる. 以上の分析により，PBLにおけ るマネジメント因子間の相関特性を把握できた．特に SEM の仮説で設定した社会人基礎力におけるメタ・コ ンピテンシーの特定, および「ほめ」による自己効力 感の向上に関しては, その妥当性が裏付けられた。

\section{6. 結論}

本研究では, PBL活性化の条件としてメンバの課題 遂行力（個力）とプロジェクトのパフォーマンス（場 力)で構成されるPBL活性化モデルについて検討した. 
個力を向上させるためには, PBLメンバのマネジメン トスキルとメタ・コンピテンシーを育成することが重 要である。一方, 場力を向上させるためには, PBLメン バのモチベーションの向上が必須条件となる. 本研究 では, 個力のコンピテンシーとして社会人基礎力を取 り上げ，そして場力向上のためにPBLにほめモデルの 導入を提案した。 その結果, 以下の結論が得られた。

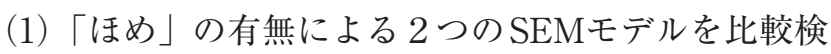
討した結果, 社会人基礎力を事例とした場合の PBL メンバのメタ・コンピテンシーを特定できた，そし て,「ほめ」がPBLメンバの自己効力感と満足度を向 上させるための重要な要因であることが分かった.

（2）SEMにより，PBLの満足度と社会人基礎力，そし て,「ほめ」との関連性を明らかにした結果,メンバ の満足度と最も関連性の高い潜在変数はシンキング であることが分かった。 ビジネス創成を目的とした PBLでは, 計画力と創造力のスキル (メタ・コンピ テンシー）を効率的に育成することが可能である.

（3）メンバの課題遂行力とプロジェクトモチベーショ ンで構成されるPBLパフォーマンスモデルを提案で きた．社会人基礎力を構成するマネジメントスキル からメタ・コンピテンシーを特定し, PBL 運用中に 適正な「ほめ」を導入すれば, PBLパフォーマンス を向上させることが期待できる.

本研究を実施するにあたり, 千葉工業大学プロジェ クトマネジメント学科学部生山際祥太氏の協力を得ま した，厚く感謝の意を表します。

\section{参 考 文 献}

1）笹川宏樹, 他：親の養育態度と自己効力感及び自 己統制感の関係, 奈良教育大学教育研究所紀要, 28, pp.81-89, 1992

2）多賀谷克彦：イノベーション まずは褒めること から, 朝日新聞, 2005. 11. 1

3) 森田洋介, 他：ほめモデルを導入したPBLコミュ ニケーションマネジメント, プロジェクトマネ ジメント学会2015年度秋季研究発表大会予稿集, pp.694-698, 2015

$4)$ Y. Morita, T. Ioi, M. Ando : Research on the Activation of PBL by Structural Equation Modeling, Proceedings of ProMAC2015, pp.54-61, 2015

5 ) K. Kameda et al : A Study of PMO Introduction for PBL Support Model, Proceedings of Pro-
MAC2015, pp.87-92, 2015

6 ) 高崎文子：ほめの効果研究のモデルについての 一考察, 熊本大学教育学部紀要, 62, pp.129-135, 2013

7 ) Brophy. J. Teacher Praise : A Functional Analysis, Review of Educational research, 51, pp.5-32, 1981

8 ) Henderlong. J. et al : The Effect of Praise on Children's Intrinsic Motivation: A Review and Synthesis, Psychological Bulletin, 128-5, pp.774 $-795,2002$

9 ）高崎文子:「ほめ」の構造とその効果 4 , 日本教育 心理学会総会発表論文集, (52), p589, 2010

10）青木直子：就学前後の子どもの「ほめ」の好みが 動機づけに与える影響, 発達心理学研究, 16-3, pp.237-246, 2005

11) Kamins. M.L. et al, Person versus Process Praise and Criticism : Implications for Contingent Selfworth and Coping, Developmental Psychology, 35, pp.835-847, 1999

12) Kast. A. et al : Sex and Age differences in response to Informational and Controlling Feedback, Personality and Social Psychology, 53, pp.383-390, 1988

13）原田奈美：チームメンバを動機付ける実践的アプ ローチ, プロジェクトマネジメント学会誌, 6-2, pp, $12-18,2004$

14）佐藤 敦, 他：組織パフォーマンス向上のため のモデルの構築と検証, 三菱総合研究所所報, 55 , pp.190-207, 2012

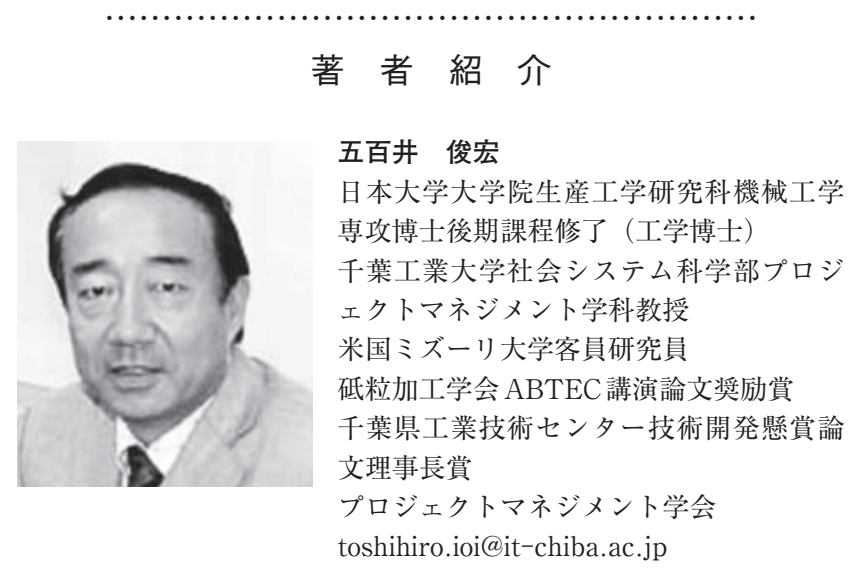

